\title{
A APAIXONADA EXALTAÇÃO DA FIGURA DE SÓCRATES POR MEIO DO LOGOS DE ALCIBÍADES NO BANQUETE DE PLATÃO
}

\author{
THE PASSIONATE EXALTATION OF THE SOCRATES FIGURE THROUGH ALCIBIAD LOGOS IN THE \\ PLATON BANQUET
}

João Raniery Silva*

\section{RESUMO}

O presente artigo pretende analisar o discurso de Alcibíades no diálogo platônico Banquete, evidenciando a forma apaixonada que o discípulo exalta a figura do mestre. Partindo de sua enigmática chegada no simpósio, presença cheia de significados, procura refletir sobre o seu plano discursivo em que acorda não elogiar a um deus, como fizera os demais convivas, mas a construção discursiva de um encômio a um homem em especial, sábio e justo, personificação mesma do erotismo pedagogicamente instruído: Sócrates. Depois da celebração desse acordo que quebra o linear caminho argumentativo do discurso, busca perceber os elementos elogiosos suplantados no referido logos, que versa a respeito das capacidades físicas, morais e intelectuais de Sócrates. Com efeito, é possível encontrar um quadro significativamente importante montado por um discípulo (Alcibíades), fazendo uso até mesmo de imagens como a dos Silenos e dos sátiros Mársias, figuras camufladoras que mostram a contradição entre realidade exterior e realidade interior, com o substancial objetivo de exaltar seu admirado mestre (Sócrates) dando-lhe características atópicas.

PALAVRAS-CHAVE: Éros. Banquete. Filosofia. Elogio. Paixão.

\section{ABSTRACT}

The present article will be analyzed in the speech of Alcibades in the platonic dialogue The Banquet, evidencing a passionate form that the learner exalts the figure of the máster: Socrates. Starting from its enigmatic no symposium, presence full of meanings, seeks to reflect on its discursive plan in what follows is not to praise a god, as the other guests had done, but a discursive construction of an encumbrance to a man in particular, wise and fair, personification same of pedagogically learned eroticism: Socrates. After the celebration of this agreement that breaks the linear argumentative path of discourse, seeks to perceive the complimentary elements supplanted in said logos, which deals with the physical, moral and intellectual capacities of Socrates. In fact, it is possible to find a significantly important picture mounted by a disciple (Alcibiades), making use even of images like the one of Silenos and the satyrs Mársias, camouflage figures that show the contradiction between outer reality and inner reality, with the substantial aim of extolling his admired teacher (Socrates) by giving him atopic characteristics.

KEY-WORDS: Éros. Banquet. Philosophy. Praise. Passione.

\footnotetext{
* Mestre em Filosofia pela Universidade Federal de Pernambuco (UFPE). E-mail: joaoraniery@ hotmail.com.
} 
No minucioso exame da natureza e benesses de Éros, tão celebrado no Banquete, é possível perceber o linear caminho argumentativo engendrado por Platão na busca de reformular o conceito e a forma como se concebia o amor dentro da sociedade grega. A busca primeira é por dar ênfase - como nos cinco primeiros oradores - a Éros como um fenômeno constitutivo da vida humana, que desemboca no papel assumido pelos cidadãos dentro de uma determinada pólis. Com o surgimento do discurso de Diotima-Sócrates, é possível perceber uma ruptura no caminho do diálogo, ruptura que marca a separação entre a intervenção socrática e a dos demais convivas do banquete. O que se vislumbra é a mudança de direção/objetivo, que leva o diálogo para um novo itinerário, julgado por Sócrates como mais frutuoso e salutar, a saber: sair do lógos meramente oratório para se chegar ao lógos propriamente filosófico. A esse passo, éros é compreendido como elemento mediador (metaxy) entre a sabedoria, o belo e a sua privação, ao mesmo tempo em que, com a explanação acerca dos graus do amor, o elogio a Éros se transforma em um verdadeiro elogio da filosofia como forma suprema do erotismo. Pois bem, é em meio a toda essa reflexão que surge no Banquete Alcibíades o qual elabora um discurso não sobre Éros e suas benesses, nem sobre a natureza e seus efeitos; mas, sobre a personificação mesma do erotismo, Sócrates, exaltando a figura de seu mestre de uma forma apaixonada. Não à toa, a enigmática entrada de Alcibíades no festim, merece uma reflexão.

\section{A PRESENÇA DE ALCIBÍADES NO BANQUETE}

Como ponto final dos vários discursos sobre Éros e, desobedecendo ao acordo estabelecido entre os convivas de manterem-se sóbrios (Banquete, 176a-c; 213e), entra na casa de Agatão Alcibíades, embriagado, sendo carregado por uma flautista, falando alto e de modo debochado, vestido com trajes escandalosos, cheio de fitas e coroado de heras e violetas. Há uma descrição minuciosa da cena em questão, como se Platão quisesse deixar para a posteridade o retrato histórico daquela situação (Banquete, 212d-e). Com o discurso trazendo à tona os ensinamentos da sacerdotisa de Mantineia, Diotima, Sócrates parecia ter chegado ao apogeu da discussão sobre a natureza e as benesses de Éros, quando então irrompe o jovem ébrio, no cenário do banquete, de forma abrupta e teatral. Esse seu modo de se comportar, um tanto extravagante, sob o efeito do vinho, põe em nítida evidência o contraste da sobriedade existente no ambiente até então (FERRARI, 2012, p. 261). 
Com efeito, o objetivo de Alcibíades, ao chegar na casa de Agatão, era o de parabeniza-lo pela vitória no concurso. Contudo, na euforia da chegada, com os olhos cobertos de fitas e se utilizando de tantos elementos em sua vestimenta, acaba não percebendo, de imediato, a presença de Sócrates, e senta-se entre este e o anfitrião do festim. Quando, então, avista o seu mestre, num salto, evoca a força de Hércules, como se estivesse em perigo (Banquete, 213b-c). E, inusitadamente, o jovem ateniense bêbado toma a coroa que tinha dado a Agatão e a entrega ao filósofo sob a justificativa de que, enquanto o poeta triunfou em apenas uma ocasião, Sócrates sempre triunfa no trato com o logos (Banquete, 213d-f). Desse modo, Alcibíades é o testemunho vivo da concretização da profecia promulgada no início do diálogo por Agatão: a de ser da responsabilidade de Dionísio, deus da embriaguez e do vinho, julgar se o filósofo (Sócrates) ou o poeta (Agatão) seria o mais sábio (Banquete, 176e). Esse embate entre filosofia e poesia será o pano de fundo das discussões em torno da natureza e benesses do Éros.

Com o confronto dialético entre Sócrates e Agatão, Platão exprime o grande ágon entre a Filosofia e a Poesia, esta já submetida ao fluxo sofistico. Explorando o amor à beleza irresistível do discurso, capaz de seduzir e arrebatar os ouvintes, sofistas como Górgias, e seu aprendiz Agatão, arrastaram as multidões e, como Platão visa demonstrar em diálogos como Górgias e A República, provocaram a ruína política de Atenas. (PINHEIRO, 2011, p. 50).

Pois bem, na sequência do texto, Erixímaco, querendo manter as regras do discurso e voltar ao clima de sobriedade e solenidade quebrado pela repentina entrada de Alcibíades, pede-lhe que, como fizeram os demais, elabore um discurso em homenagem ao amor. Ou seja, na busca de conter os excessos do controverso político ateniense, sugere que não fique apenas consumindo vinho, mas elabore um elogio a Éros. Contudo, conhecendo a singular personalidade de Alcibíades, era de se esperar que não aceitasse tão facilmente o que se estava propondo. Sob a justificativa de estar inebriado pelos efeitos da bebida, se sentia incapaz de elaborar um elogio à altura daqueles desenvolvidos até então. Mesmo assim, aceita o desafio! Compromete-se em elevar um elogio ou encômio, não ao deus Éros, mas a Sócrates, através de sua própria experiência e convivência com ele, em vista da verdade (talethê erô) (Banquete, 214b-e). Alcibíades não falará do amor em geral, mas do seu próprio amor, em sua vivência com seu mestre, Sócrates. Até porque, de acordo com ele, se assim não fosse feito, Sócrates ficaria enciumado, se, ao invés de elogiá-lo, elogiasse o deus. "Se é um 
elogio que esperam de mim, impossível! Sócrates é tão ciumento que, diante dele, me é proibido elogiar quem quer que seja, homem ou deus!" (Banquete, 214d ).

Sendo assim, pede o acordo (homologia) de todos, quanto à autorização para transformar um tributo a Éros na expressão de seu próprio desejo, configurado no elogio de um objeto erótico particular: Sócrates. Assumindo essa postura, Alcibíades deixa explícita a paixão que o consome pelo seu mestre, o que o leva a pronunciar um louvor que se torna prova cabal do poder de Éros sobre a linguagem e o comportamento humano (OLIVEIRA, R., 2016, p. 58). Com esse pedido de mudança da regra, saindo do elogio a Éros para o elogio à Sócrates, Alcibíades inverte, automaticamente, as posições em uma relação eróticopedagógica: de amado (erômano) passa a ser amante (erasta). Tal empreitada se dá na busca de refutar a postura de Agatão, por meio de mais bebida, pois assim poderia elaborar o verdadeiro elogio a Sócrates. Há, portanto, um deslocamento significativo do diálogo do discurso apolíneo para o dionisíaco, por ser sob o efeito do vinho que se formulará o discurso sobre Sócrates.

Dessa forma, se justifica a entrada de Alcibíades embriagado na cena do Banquete, que se dá no exato momento em que Sócrates é aplaudido e louvado pelo seu bem construído discurso, no qual exalta o controle, o domínio de si e a busca para além das coisas unicamente físicas, arma contra o amor pessoal. Com efeito, como foi visto no processo de individualização do belo, enfatizado pela sacerdotisa de Mantineia, Diotima, a pedagogia erótica ultrapassaria o exercício intelectual, visando muito mais o constante e necessário equilíbrio na dose adequada do desejo na vivência humana. Em outras palavras, tem-se aqui o contraste entre vida e teoria pela primeira vez no Banquete. O que Platão pretende, nesse momento, é evidenciar que o amor socrático não é algo apático e distante da realidade do indivíduo. Não há uma “impessoalidade" no Éros platônico. Para tanto, apresenta o ponto de vista de Alcibíades, alguém que experimentou esse amor total e extremamente pessoal (realidade cabível ao amor dos mortais). Desse recurso filosófico-retórico trata, substancialmente, Martha Nussbaum, acreditando que nessa passagem há algo de novo que se abre para uma reflexão, fazendo com que o leitor retorne à pergunta inicial: "quem é Éros?" (NUSSBAUM, 2009, p. 145). Por conseguinte, Sócrates, ao perceber que seria ele o elogiado e não Éros, se sente apreensivo. O motivo disso está em supor que Alcibíades, em vez de louválo, teria como objetivo realizar o seu plano de vingança, ao caricaturá-lo e ridicularizá-lo. Contudo, o ébrio jovem se compromete com a exigência de que tudo que irá falar a respeito do filósofo será a verdade (aletheia). Fato é que não será o tipo de verdade falada quando se 
está sóbrio (impossível diante da condição de Alcibíades), mas nem por isso menos verdade. Ao passo que Sócrates está autorizado a interromper seu elogio a qualquer momento, caso a aletheia lhe falte (Banquete, $214 \mathrm{e}$ ).

\title{
2 SÓCRATES COMO IMAGEM MESMA DE ÉROS
}

$\mathrm{Na}$ elaboração do elogio a Sócrates, Alcibíades informa que deverá começar sua construção através de uma comparação, de uma imagem (he eikón), que será escolhida, de acordo com ele, em função da verdade. Sendo assim, a série de imagens que será contada, por ser fruto da aletheia, deverá excluir toda forma de riso ou deboche. O que Alcibíades está propondo é que ele procurará contar sua experiência de amor com Sócrates, em que, de forma consequente, revelará um Sócrates idêntico ao Éros revelado no discurso socrático. Há uma comparação, então, de Sócrates às figuras do Sileno e do sátiro Mársias ${ }^{1}$, tendo, tanto uma figura quanto a outra, a função de camuflagem e máscara dissimuladora de Sócrates.

\begin{abstract}
Silenos e Sátiros eram na representação popular demônios híbridos, metade animais, metade humanos, que formavam o cortejo de Dionísio. Impudentes, bufões, lascivos, eles constituíam o coro dos dramas satíricos, gênero literário do qual o 'Ciclope' de Eurípides permanece um dos raros testemunhos. Os Silenos representam, então, o ser puramente natural, a negação da cultura e da civilização, a bufonaria grotesca, a licenciosidade dos instintos. (HADOT, 2012, p. 9).
\end{abstract}

O entusiasta político ateniense descreve a imagem do mestre como possuidor de um físico nada aprazível, parecido com os Silenos (silenoîs) ${ }^{2}$, que exteriormente não possuem beleza, mas contêm dentro de si pequenas estátuas de deuses. Assim é Sócrates: apesar de sua aparência física desconcertante, é possuidor de uma beleza incomum e supreendentemente inusitada. Com efeito, o referido filósofo manifesta a própria contradição viva, em seu paradoxo: feiura exterior, por um lado, e beleza interior, por outro.

Sabe-se quão notória era a feiura de Sócrates, quase uma afronta a uma sensibilidade acostumada com as linearidades, harmonias e equilíbrios plásticos da estatuária e da

\footnotetext{
${ }^{1}$ Não é difícil de perceber essas duas características elencadas por Alcibíades em seu discurso, como se poderá ver. Em seu exterior, Sócrates possui aspecto feio, bufão, monstruoso, mas isso lhe serve apenas como uma máscara, de forma que a Sócrates bem se adequa o comentário de Nietszche (2006, p. 71): “Tudo nele é dissimulado, retorcido, subterrâneo".

${ }^{2}$ É importante registrar aqui que Alcibíades, ao representar Sócrates como Sileno, não permanecerá sozinho. Como observa Zanker (1995, p. 32-39), essa imagem do filósofo será retomada entre dez a vinte anos após sua morte. É bastante significativo que, em um contexto em que a beleza e a perfeição simétrica das curvas do corpo humano eram cultuadas, Sócrates seja pintado como um desconcertante sileno.
} 
arquitetura da época. Mas se o seu exterior é feio e quase repulsivo, seu interior deixa vislumbrar belas imagens que proclamam a divindade de sua alma, beleza interior a contrastar com a feiura do rosto. [...] Feio no exterior e belo no interior, Sócrates, essa 'contradição viva', é como os silenos - deuses campestres da corte de Dionísio com cauda e cascos de boi ou de bode e rosto humano - que escondem em si mesmos deuses inesperados. Do mesmo modo que os silenos eram seres monstruosos, semi-animalescos ou semi-humanos, nem animais nem homens, Sócrates encarna, por seu corpo e por sua alma, esse estado intermediário já figurado por Eros no discurso de Diotima. (MACEDO, 2003, p. 412-413).

Essa ambivalência entre as características físicas e as interiores de Sócrates, dono de um contraste questionador, inquieta todo aquele que se dedica a pesquisar a filosofia antiga. Torna-se, com efeito, significativo que, até onde se sabe, Sócrates tenha sido o "primeiro grego ilustre feio", onde "tudo é excessivo, bufão, caricatural...", tendo como descrição autêntica de sua fisionomia os seus "olhos de lagostim, seus grossos lábios, sua pança" (NIETZSCHE, 2006, p. 71). É revolucionária a mensagem platônica, ao propor, em uma sociedade grega que um homem belo e festejadíssimo como Alcibíades ame um homem grotescamente feio como Sócrates. Ora, parece não haver um exagero na descrição comparativa de Alcibíades em relação ao seu mestre. Esse personagem histórico, como concordam inúmeros pesquisadores, deve ter possuído um aspecto impressionantemente feio ${ }^{3}$. E isso acabava por se manifestar como algo ofensivo, já que ele praticava atividades intelectuais. De fato, a feiura de Sócrates era um clamor para uma discussão filosófica. Já na descrição de suas características físicas, seria o início de um longo e questionador discurso platônico sobre o Belo e o Bom.

\begin{abstract}
Para um povo tão agarrado à beleza das formas, tão amante da harmonia plástica, que considerava um dom divino, signo de perfeição interior, Sócrates é uma contradição viva: é tão evidentemente feio quanto é inteligente, vivo de sabedoria brilhante [...]. Sua feiura é provocante, mas é belo (é assim que a ele se refere Platão) [...]. Sócrates encarna para os gregos a oposição entre o ser e o parecer, entre a alma e o corpo, oposição que se transformarão no fundamento de suas reflexões e das quais ainda somos tributários. (WOLFF, 1982, p. 15).
\end{abstract}

Só poderia, nesta empreitada, ter havido a mudança de postura que era o intento socrático: em vez de amar o físico e o exterior, o homem deveria amar a beleza interior que transcenderia tudo o que existe. Substancialmente, a utilização da figura silênica, remontando ao hibridismo belo-feio, deve ser assimilada como uma realidade positiva, proposta,

\footnotetext{
${ }^{3}$ A título de exemplo, pode-se citar ZANKER (1995, p. 34), quando confirma - junto com inúmeros outros - a ausência de beleza no aspecto físico de Sócrates.
} 
possivelmente, por Sócrates mesmo. Isso tudo com o objetivo de lançar as bases para uma nova interpretação comparativa e irônica.

\begin{abstract}
A decisão de adaptar a comparação com Sileno para uma estátua ou retrato destinado a celebrar o assunto, no entanto, pressupõe uma interpretação positiva da comparação, como nós de fato encontramos, em particular, no discurso de Alcibíades no Banquete, de Platão. Talvez o próprio Sócrates já tenha colocado as bases para essa nova interpretação, aceitando a comparação com a sua característica ironia. (ZANKER, 1995, p.34).
\end{abstract}

E ainda mais: Alcibíades, usando a figura dos Silenos, elucida a pedagogia socrática por excelência: o autoexame. Seria preciso esse "olhar para dentro", o chamado princípio do "conhece-te a ti mesmo", que desemboca no cuidado de si, dando ao socratismo sua singularidade ${ }^{4}$. Já no início do discurso, na casa de Agatão, é possível entrever esse exame interior. Sócrates é descrito, em sua chegada ao simpósio, como alguém que, espiritualmente, está ocupado consigo mesmo, motivo do seu atraso (Banquete, 174d). Mais enfática ainda é a resposta de Aristodemo, quando trata com naturalidade este episódio: “deixai-o em paz. É costume (éthos) dele" (Banquete, 175b). Não diferente disso, até mesmo Alcibíades em seu elogio, como veremos, faz uma alusão a esse hábito socrático de se autoanalisar (Banquete, 220c). Em suma, Alcibíades está falando de sua experiência amorosa com Sócrates. E por estar falando de uma realidade tão intima, inevitavelmente, já teria visto esses arroubos de sondagem interior de seu mestre. Até porque o filósofo, para ele, é aquele "que vence em argumentos todos os homens" (Banquete, 213e), uma figura além do normal, que bebe e não fica embriagado (Banquete, 214a), que mais se parece com os silenos que escondem um tesouro dentro de si (Banquete, 215b). Em síntese, o que aqui se encontra é um louvor à sabedoria socrática.

\footnotetext{
${ }^{4}$ Essa questão do cuidado de si, que aparece no Banquete, é uma temática recorrente em outro diálogo de Platão: o Primeiro Alcibíades, que é considerado por alguns pesquisadores como um escrito apócrifo. Contudo, deixando de lado as divergências quanto à autenticidade desse escrito, e mantendo-se no aspecto temáticofilosófico, parece ser salutar uma elucidação sobre a questão do cuidado de si, já discutido nesse questionador diálogo. Na oportunidade descrita na obra, há uma conversa entre Sócrates e o político Alcibíades, em que este pergunta àquele de que maneira pode se dar o cuidado de si. Sócrates the responde utilizando da metáfora do espelho (Primeiro Alcibíades, 130b-133c): da mesma forma que para olhar para si mesmo é necessário que o olho veja outro olho, analogamente acontece com o "si próprio". O "si" do homem, para Platão, é sua alma (Primeiro Alcibíades, 130c; 130e). Então, se a alma quer conhecer a si mesma, deve olhar outra alma em sua parte excelente. Da mesma forma que a excelência do olho está na pupila, a da alma está na sabedoria. Sendo assim, descobrindo essa porção sábia da alma que contém o conhecimento e a reflexão, todo aquele que para ela se volta descobre sua totalidade excelente, sendo possível se autoconhecer. Em suma, como a própria figura do Sileno propõe, no Banquete, é preciso sempre "olhar para si mesmo", em um desejo autêntico e necessário de se autocontemplar. Pois "é 'conhecendo' que a alma cuida de si mesma, realiza a própria purificação, se converte e se eleva. E nisso reside a verdadeira virtude". (REALE; ANTISERI, 2003, p. 256).
} 
Além desta primeira alusão, Sócrates é comparado com o sátiro Mársias, desafiador de Apolo com sua flauta (Banquete, 215b). Não é apenas equiparado na aparência externa, mas em sua realidade interior e cognitiva, por ser considerado insolente (hybristés) e um terrível encantador. Com efeito, enquanto Mársias seduz e hipnotiza os homens, levando-os ao transe com o poder misterioso de sua flauta, Sócrates, por seu turno, produz efeitos semelhantes, sem mesmo usar do recurso de instrumentos musicais. $\mathrm{O}$ único meio utilizado por Sócrates para conseguir tal intento é através de suas simples e acertadas palavrasdiscursos. Dessa forma, encanta e subjuga seus ouvintes e interlocutores, com uma eloquência difícil de ser resistida, a qual nenhum orador é capaz de superar (Banquete, 215b-217a).

Se se pudesse olhar sob o prisma do jovem ateniense, seria possível constatar este quadro propositivo: um discípulo que fora ensinado pelo seu mestre que Éros seria algo tão sublime e veraz, capaz de impulsionar todos aqueles que se deixam pedagogicamente conduzir ao ápice mesmo das coisas do amor; no entanto, Sócrates, que seduz para depois desprezar, descreve a si mesmo como sendo Éros, em um discurso tão egoísta quanto o de seu discípulo; um Sócrates, enfim, que se diz refratário a atrair-se por aquilo que primeiro lhe chamou a atenção e que usa as qualidades físicas de seus jovens como sua moeda de troca. $\mathrm{E}$ quando esses jovens (aqui, no caso, Alcibíades) são convencidos a seguir e admirar o mestre, levando em conta que possui um valor de troca (um, a sabedoria; o outro, a beleza), Sócrates inverte sua metodologia e passa a desvalorizar o que é ofertado pelo outro (a juventude e a beleza), ficando em total vantagem. Com a resposta de Sócrates, Alcibíades percebe sua indignidade em receber o amor de seu mestre, mesmo sendo belo e estando em plena jovialidade. Embora Sócrates possuísse um aspecto exterior feio como o Sileno e o sátiro Mársias, era dono da melhor e mais necessária qualidade, a sabedoria. Como trocar apenas beleza e a juventude, que são passageiras, por um tesouro tão mais elevado, como a sabedoria, que é eterna? Essa proposta lhe é desconcertante: seria como que trocar bronze por ouro (Banquete, 218d-219a). Ora, a utilização das máscaras dos Silenos e dos Mársias é uma forma dissimuladora encontrada por Sócrates, de acordo com os diálogos platônicos, de desenvolver a sua ironia.

Sócrates triunfou mesmo tão perfeitamente nesta dissimulação que se mascarou definitivamente para a História. Nada escreveu, contentou-se em dialogar e todos os testemunhos que possuímos sobre ele o ocultam mais do que o revelam a nós, precisamente porque Sócrates sempre serviu de máscara àqueles que falaram dele. Porque ele se mascarava a si mesmo, Sócrates tornou-se o prosópon, a máscara, de personalidades que tiveram necessidade de se proteger atrás dele. Ele lhes deu ao mesmo tempo a ideia de se mascarar e a de tomar como máscara a ironia socrática. 
Existe aí um fenômeno extremamente complexo por suas implicações literárias, pedagógicas e psicológicas. (HADOT, 2002, 105).

Há uma transfiguração socrática que finge ignorância e impudência. O próprio Alcibíades, no Banquete, afirma que tanto as aventuras amorosas de Sócrates como sua autointitulação "ignorante" seriam uma espécie de artifício exterior com o qual se veste, aos moldes de um Sileno esculpido (Banquete, 216d-e ). Sob o modo de atuar platônico-socrático, Hadot interpreta essa utilização da máscara irônica de Sócrates como uma forma sutil e refinada de colocar o leitor na posição de interlocutor, o qual será conduzido pelas questões socráticas sem saber, previamente, aonde elas o levarão. Dessa forma, a máscara de Sócrates imputa uma perturbação na alma do leitor, desconcertando-o. Contudo, possibilita-lhe a uma tomada de consciência de que o melhor caminho a ser seguido será o da conversão filosófica (HADOT, 2012, p. 11). Dessa forma, a representação trazida pelas figuras através do discurso de Alcibíades é um modo de mostrar ocultando outra coisa. Mesmo no comum das coisas reais, Sócrates se dispõe a sair da banalidade dos assuntos pífios, lugar onde seus interlocutores se encontram, para alçar voos rumo à natureza mesma de Éros.

\begin{abstract}
A estátua do Sileno é uma aparência que oculta outra coisa. Assim são as palavras de Sócrates. Partindo da linguagem comum, de assuntos comuns, ele traça caminhos pelos quais seu interlocutor entra em choque consigo mesmo. À banalidade dos assuntos corresponde a banalidade dos interlocutores; Sócrates é um homem da rua e seus interlocutores são encontrados na rua. Mais que isso, a autodepreciação é componente essencial da máscara irônica. [...] a ironia é uma atitude psicológica na qual o indivíduo parece inferior ao que ele é. No uso do discurso, tal disposição consiste em fingir dar razão ao interlocutor. (OLIVEIRA, L., 2016, p. 329).
\end{abstract}

Não é muito difícil de se encontrar, na tradição de comentadores platônicos, a ideia sempre pujante de um desprezo de Sócrates pelo que é físico, quase como se fosse uma prerrogativa para uma virtude no amor. Essa visão não é muito aceita por Robin, para quem, se se concorda que Sócrates não é fascinado pela exuberante beleza exterior de Alcibíades, moeda de vantagem utilizada pelo jovem ateniense para cortejar o filósofo, deve-se admitir, sumariamente, que a força da alma e a temperança socráticas não seriam colocadas à prova, inviabilizando quaisquer argumentos que procurem provar um Sócrates possuidor de um extraordinário domínio sobre o corpo. Em outros termos, sem o fascínio de Sócrates pela beleza do jovem discípulo, não seria possível um exercício verdadeiro da alma quanto à temperança, o que tornaria impossível, portanto, a verificação da característica mais fundamental de Sócrates: a de ser ele conduzido pela parte superior de sua alma, e não pelo 
seu corpo. Com efeito, é esse domínio do sôma que o torna atraente, irresistível, misterioso... E ainda mais, dominando o corpo, Sócrates mantém - incólumes - ao seu redor os jovens atenienses, fazendo-os compreender que a sua feiura é como que um esconderijo de uma joia valiosa (por isso a imagem das estatuetas de Silenos e sátiros Mársias).

De acordo com Irley Franco (2008, p. 71-73), se bem interpretado, embora Sócrates paute seu domínio de si por meio do desprezo do físico, atrás dessa postura se esconde um filósofo que se abstém de nutrir um amor pelos seus, por meio de inúmeros subterfúgios que o livrem da posição de amante (posição mais conveniente para o mestre em uma relação pederasta). O próprio Alcibíades atesta, com amargura, essa postura de Sócrates que engana amar, quando na verdade é um simples amigo: “[...] ele enganou, fingindo-se amante, para revelar-se, por fim, simples amigo" (Banquete, 222b). Desse modo, não há perigo de Sócrates se apaixonar loucamente por seus discípulos. Para Franco, por Sócrates ser dono de si, ele seria incapaz de amar aqueles que entrassem com ele no processo erótico-pedagógico. Prossegue essa argumentação mostrando os motivos da incapacidade de Sócrates amar: (1) porque o desejo autenticamente erótico está nele ${ }^{5}$; (2) porque o desejo pelo corpo, como já atestado por Diotima na scala amoris, é apenas ponto de partida para se desejar o absoluto; e, por fim, (3) porque não é exatamente Alcibíades que Sócrates não ama, o problema não está de forma específica no discípulo, mas em qualquer um que o busque com essa intenção. Conclui-se, assim, partindo das questões próprias expostas no Banquete, sobre a proposição de Sócrates tornar-se alheio a quaisquer amores ofertados pelos seus discípulos, escapando da postura de amante e se fixando, sempre que possível, na postura de amado.

Dando continuidade à construção do elogio, Alcibíades mostra como os discursos de Sócrates exercem efeitos devastadores sobre ele, impossibilitando-o de não ser totalmente embriagado e apaixonado pelo filósofo. Analogamente, assemelha os efeitos dos logoi de Sócrates em sua alma aos êxtases convulsivos pelos quais passam os coribantes ou até mesmo às dolorosas e violentas mordidas das víboras. Apesar de possuir todo esse brilhantismo, Sócrates, segundo Alcibíades, não se aproveita sexualmente dos que ele entorpece. Ao contrário, procura se manter temperante frente aos atrativos físicos ou corpóreos de seus discípulos, apesar das inúmeras investidas eróticas que o próprio Alcibíades confessa ter

\footnotetext{
${ }^{5}$ Franco chama a atenção para a necessidade de desvencilhar a imagem de Sócrates da de um asceta que estaria fingindo ser atraído sexualmente pelos jovens, com o objetivo único de juntar "amantes do belo". A essa interpretação se assemelham alguns comentadores com características moralistas, que sentiam dificuldade de unir o desejo à filosofia. Um exemplo desses é Lacan (1991), que faz um comentário importante criticando a relação "escandalosa" entre Sócrates e Alcibíades.
} 
empreendido. Mesmo em meio a intensas investidas, Sócrates se mantém em perfeito estado de moderação e continência sexual, sem ceder em nenhum instante aos apelos sexuais de seu pupilo $^{6}$. Sua única preocupação, no entanto, quando se referia a Alcibíades, era em educá-lo moralmente, para que chegasse a sua excelência. Ora, essa forma ambígua de se elogiar Sócrates evidencia muito mais a personalidade do autor do elogio que propriamente o elogiado $^{7}$. Parece que Alcibíades se encontra dentro das duas características de seu mestre.

Quase que paradoxalmente, de um lado, quando apresenta um Sócrates que sobre ele exerce um grande poder, tocando nas partes mais profundas de seus sentimentos (emoção, raiva, paixão,...) ao mostrar como sua vida é subjugada e, até, escravizada pelo desejo, requerendo, por isso, mudança, deixa entrever seu mestre como um protótipo ou ideal (Banquete, 215d-216e); por outro lado, Alcibíades é incapaz de colocar em prática todos os objetivos formulados a partir dos discursos socráticos, ao escolher as vantagens do "agora", em detrimento daquelas "futuras" que a filosofia aponta. Dessa forma, a partir da dualidade encontrada no discurso de Alcibíades, é formado um quadro "a favor" e "contra" o filosofar. Em Sócrates, Alcibíades se vê atraído pelos irresistíveis logoi, os quais destruiriam e tragariam sua ambição política. Com efeito, se o jovem ateniense procura respaldo na filosofia para suas ambições políticas e estadistas, estimuladas por valores questionáveis que visam unicamente à vontade pessoal e a uma pseudoética que promovia interesses individuais e subjetivos, então, de fato, a filosofia seria um perigo para ele. Perigo porque estar na trilha do filosofar é estar propenso a destruir as suas crenças e mitos pessoais. Para tanto, precisa fugir, se esconder, cerrar os seus ouvidos para não ouvir o irresistível canto da sereia, ou até mesmo fazer "ouvido de mercador" para as exigências socráticas que seriam como uma mordida mortífera de uma víbora na alma e no coração. Ora, nesse ponto, o elogio de Alcibíades evidencia o eterno paradoxo que o habita e lhe consome em seu interior: uma influência que

\footnotetext{
${ }^{6}$ Parece ser ponto pacífico que a relação existente entre Sócrates e os jovens que o seguiam era totalmente homoerótica, sendo possível encontrar diversas testemunhas desse fato. Tendo como base os vários exemplos na literatura antiga, seria impossível, como elucida bem Paul Friedlãnder (1969, vol. 1) compreender Sócrates como sendo não erótico, como sendo um tipo de educador-sedutor-ascético.

${ }^{7}$ A ambiguidade na forma de se elogiar Sócrates, encontrada nas palavras de Alcibíades, já é uma característica sempre presente nos discursos socráticos (lógoi sokratikoî), nos quais Sócrates sempre aparecia assumindo uma máscara. Contudo, o que faz Platão ser verdadeiramente original não é o fato de colocar Sócrates como elemento principal de seus escritos, mas, como diz Dorion (2006, p. 24 et sq.), de identificá-lo de modo totalmente diferente, enfatizando seu caráter paradoxal: "um dos numerosos paradoxos do personagem Sócrates, tal como é representado por Platão, é que ele é ao mesmo tempo e simultaneamente virtuoso e desencorajador, benevolente e incompreensível, amável e astucioso". Não é à toa que, em toda tradição do pensamento filosófico, Sócrates é tido como inapreensível, imprevisível, estranho, feio e dissimulado.
} 
lhe é fortemente arrebatadora, contra a incólume e constante revolta que essa influência lhe causa devido às perdas que acarreta.

Pois bem, quando se trata das imagens dos Silenos e dos Sátiros Mársias, paradoxo entre "ser" e "parecer", realidades naturalmente ambíguas, parece Platão querer propor a necessidade de que haja uma devida distinção entre "mediador" e "mediação" (HADOT, 2002, p. 93). Quando se usa o termo mediador pretende-se referir a algo que está entre uma coisa e outra, definidamente, um terceiro componente entre duas realidades extremas. Assim, seria um elo, como se fosse um amálgama, que ligaria as duas realidades divergentes. Nesse caso, não precisaria de traços das duas extremidades, apenas que mediasse as suas diferenças. Contudo, a ideia de mediação, transmitida com a comparação dos Silenos e dos Sátiros, mais se equipararia a Éros. Seria algo semelhante a um justo meio, o equilíbrio entre uma realidade e outra. Possuidor das partes extremas, figuraria uma harmonia que poderia se mesclar entre o divino e o humano, entre a sabedoria e a ignorância, entre o belo e o feio. Assemelhando-se, assim, às características propriamente socráticas que são desconcertantes, ambíguas e inquietantes. $\mathrm{O}$ amor é mais que mediador, é mediação.

O filósofo aparece, no elogio de Alcibíades, como um perfeito exemplo de temperança e autocontrole. Pois, embora esteja sempre à procura dos jovens mais belos e talentosos de Atenas, sua busca primordial era, em vez da beleza dos seus corpos, o melhoramento moral de suas almas. Mas isso não é tudo. O elogio de Alcibíades ao seu mestre, num segundo momento, versará sobre sua capacidade física. De acordo com o controverso jovem político, Sócrates possuía uma resistência extraordinariamente sobrehumana. Evidência disso é o fato de o filósofo, quando em tempo de penúria e escassez de comida, suportar os longos períodos de jejuns; ou mesmo sua resistência aos extremos do clima, sendo ele capaz até de andar descalço em pleno inverso, sobre a neve. E não só isso: quando a situação era contrária, quando estava em tempo de fartura, acrescenta Alcibíades, Sócrates era capaz de beber grande quantidade de vinho, sem nunca se embriagar. Dessa maneira, o discípulo elucida o rigor do mestre sobre si mesmo, dominando qualquer condição, até mesmo aquela provocada pelo excesso de álcool (Banquete, 219e-220b ).

Dando um passo adiante, Alcibíades prossegue seu elogio tratando da capacidade de contemplação de Sócrates. Se, por um lado, o elogiado possui uma resistência física extraordinária, chegando a ser sobre-humana, digna, portanto, de uma louvação, por outro lado, era capaz de passar longos períodos em contemplação, absorto em seus pensamentos, 
em uma reflexão sem medidas, profunda e intensa (Banquete, 220b-c) ${ }^{8}$. E ainda mais: unindose a tudo isso, Alcibíades eleva uma louvação à coragem de Sócrates. De acordo com ele, eram inquestionáveis a virilidade e a bravura militar de seu mestre. Essa caraterística é bem ilustrada pelo jovem político, ao relatar a experiência por ele vivida com Sócrates por ocasião das expedições de Délio e da Potideia; nessas expedições, Sócrates, de fato, o salvou por duas vezes, evidenciando seu caráter destemido e indiferente à morte e aos perigos da dor (Banquete, 220c-221c). Com isso, depois de ter elogiado as capacidades físicas, morais e intelectuais de Sócrates, Alcibíades constrói a última parte do louvor ao seu mestre exaltando sua personalidade que fugiria de todos os padrões, em nada comparável aos heróis do passado e do presente. Em outras palavras, Sócrates é considerado um átopos.

\begin{abstract}
Reconhecendo todas essas qualidades físicas, morais e intelectuais no filósofo, Alcibíades é levado, assim, a exaltar o caráter inclassificável de Sócrates, vale dizer, o fato de Sócrates ser realmente uma personalidade inteiramente fora dos padrões, impossível de ser comparada a qualquer herói do passado e do presente. Homem de exceção, verdadeiramente único, Sócrates é completamente atópico, poderíamos dizer, e a sua atopia the confere uma supremacia indiscutível sobre os demais humanos e mortais (OLIVEIRA, 2006, p. 59) ${ }^{9}$.
\end{abstract}

No filósofo de pés descalços, de acordo com Dorion (2006, p. 26), a atopia é encontrada precisamente em sua ironia: seja na simulação de sua total ignorância, deixando que aqueles que dizem saber se apresentem como superiores a ele; seja na constante prática da refutação (élenkhos), que deixa seus interlocutores em profunda perturbação ${ }^{10}$. Sócrates é a encarnação mesma de Éros. Como visto até então, há uma intervenção inesperada de Alcibíades no Banquete, um "golpe teatral como drama satírico-silênico", uma vez que o jovem Alcibíades trata do significado de Eros em consonância com o significado do verdadeiro amante. Existe, então, uma passagem da discussão teórica ao drama satírico que pretende refletir o que se passa na vida real. Além da reflexão sobre a natureza e as obras de Eros, a teoria se personifica na vida real, e em correspondência com o paradigma do amor como "amante" se mostra sua imagem, encarnando-se em um homem, Sócrates.

\footnotetext{
${ }^{8}$ Nesse ponto Platão alude à questão já mencionada e refletida neste trabalho, concernente à misteriosa parada de Sócrates ao se dirigir à casa de Agatão (Banquete, 174d-175f).

${ }^{9}$ Alguns comentadores, quando querem tratar das características, para eles, inclassificáveis, utilizam-se do termo "átopos". Hadot (2002, p. 27) elucida sobre o significado de tal palavra: "a palavra significa etimologicamente 'fora de lugar', logo estranho, extravagante, absurdo, inclassificável, desconcertante" (Banquete, 221c-d).

${ }^{10}$ Quanto ao élenkhos praticado por Sócrates, vale conferir a passagem da Apologia de Sócrates em que o filósofo é comparado ao tavão, uma espécie de mosca, à qual é dada a tarefa de perturbar os grandes e nobres cavalos preguiçosos, na busca de pô-los em movimento. É assim que Sócrates se identifica: como sendo uma mosca irritante que, frente aos homens (representados pelos cavalos nobres e grandes), interroga-os e refuta-os insistentemente (Apologia de Sócrates, 30).
} 
Esse homem, como encarnação suprema de Eros, se equipararia com Silenos e Mársias: embora feio e de beleza desprezível por fora, por dentro possui um grande tesouro, podendo entorpecer com seus discursos como a sereia que prende suas presas unicamente com o canto. Não poderia ser diferente: existe uma inversão dos papéis de amante e amado efetuada por Sócrates (REALE, 2004, p. 248). Com efeito, Sócrates e Alcibíades, amado e amante, invertem as posições e, como sua ligação propõe uma chave interpretativa, substancialmente importante, para se bem compreender o diálogo em questão. "Amado e amante formam um amálgama que aparentemente subverte a trama dramática e especulativa do Banquete, mas, ao contrário do que possa parecer, confirma, instrui e fornece uma chave interpretativa que é fundamental para compreendê-lo em sua inteireza" (MACEDO, 2003, p. 408). E ainda mais, quando Sócrates inverte essa posição, realiza, automaticamente, cada grau da scala amoris, sob os moldes do exercício erótico. Construindo em si mesmo o protótipo do filósofo, encarnando os vários modos de Eros - desde seu impulso inicial - impulsionando e articulando o seu possuidor em todos os seus mo(vi)mentos (MACEDO, 2003, p. 408).

Desse modo, Sócrates não seria apenas um pensador e questionador das leis e política atenienses, mas um possuidor de características necessárias para o governo da pólis, o verdadeiro filósofo e o perfeito erótico, o elo que completa a ligação entre ignorância e sabedoria, feiura e beleza. Ou seja, é filósofo ideal, por saber que não é perfeito nem, muito menos, acabado; por saber que tem dentro de si a dýnamis erótica, própria daqueles que, ao assumir suas carências e imperfeiçoes, almejam, paulatina e continuamente, alcançar o que não se possui. A postura do filósofo para Platão é aquela que se desprendeu, através do conhecimento e da reflexão acerca da verdade, das correntes que aprisionavam o homem na caverna, e a partir disso consegue ver e enxergar o mundo intangível, o mundo onde as formas são perfeitas, o mundo das ideias, onde a verdade da imutabilidade das coisas predomina. E que, por fim, depois de vista a luz, não consegue mais ficar nas sombras e imperfeições das formas, dentro da caverna. O filósofo não é aquele que tudo sabe, mas sim aquele que deseja saber, que busca incansavelmente o conhecimento, que está disposto a qualquer sacrifício para encontrar a verdade. E é a busca pela verdade (e já a busca!) que faz o filósofo ser o que se é. "Para Platão, o distintivo maior do filósofo é a busca da verdade. Caberá, portanto a este empreender um pensamento capaz de retirar o homem deste relativismo epistemológico em que o colocou o sofista, e a conduzi-lo à rocha firme do conhecimento verdadeiro." (RIBEIRO, 2005, p. 19). 
O Banquete se desenrola evidenciando que o homem só terá a verdadeira felicidade se descobrir no amor-filosofia o meio para se tornar o melhor possível. Logo, aquele que se dedica a filosofar deve ser como uma parteira que deixa vir as ideias. O filosofar vem da geração e da parturição "porque é algo de perpétuo e imortal para um mortal, a geração" (Banquete, 207a ). O elogio feito por Alcibíades a Sócrates nada mais é que a exibição, em um exemplo palpável, de tudo aquilo que Diotima falara anteriormente; mostrar que é possível alcançar este amor-filosofia, a exemplo de Sócrates, que já o tinha encontrado. Ele, de fato, é a encarnação desse Éros, chegando até, no louvor de Alcibíades, a se confundir com as características do amor, como em uma verdadeira fusão. Nesse modo de elogiar Sócrates, parece Alcibíades confundir quem é Éros e quem é seu mestre. As características se equivalem.

\footnotetext{
De uma extremidade a outra do diálogo, mas sobretudo no discurso de Diotima e no de Alcibíades, percebe-se que os traços da figura de Eros e os da figura de Sócrates tendem a confundir-se. E, finalmente, se eles se entremeiam tão estreitamente, a razão é que Eros e Sócrates personificam, um de maneira mítica, outro de maneira histórica, a figura do filósofo. Tal é o sentido profundo do diálogo. (HADOT, 1999. p. 72).
}

Sendo assim, ao elogiar Sócrates, Alcibíades está elogiando o papel dos verdadeiros filósofos, daqueles que procuram a verdade, daqueles que auxiliam os homens a serem os melhores possíveis: "a mim, com efeito, nada me é mais digno de respeito do que o tornar-me eu o melhor possível, e para isso creio que nenhum auxiliar me é mais importante do que tu [Sócrates].” (Banquete, 218d). A filosofia de Platão sempre partirá da manifestação empírica para alcançar o princípio mais essencial. É, pois, por amor à beleza física - como visto causada a partir do espanto por ela impetrado, que a filosofia procura conhecer o mundo e se dedica ultrapassar as suas aparências, buscando o fundamento último do divino, do espiritual e do inteligível. Por meio de Éros, o amante anseia conhecer com profundidade o amado, transcende aquilo que os olhos podem ver. Ora, esta será sempre a provocação feita por Sócrates a seu apaixonado-discípulo Alcibíades: que ele penetre, o mais profundamente que puder, o seu olhar, para conhecer o seu interior. Com efeito, o amor intensifica e aprofunda o olhar; e, aprofundando, transforma aquele que se dispõe a isso (KENAAN, 2010, p. 157-176).

Necessariamente é este o compromisso do filósofo: fazer de todos os que dele aproximam os melhores e mais autênticos possíveis. Então, será impossível o discípulo que proficuamente aprendeu as lições de seu mestre não se apaixonar pelo Belo que existe dentro 
do educador. Por mais que o mestre não tenha beleza exterior, se ele estiver comprometido com o crescimento humano de seu discípulo, o senso de beleza saltará aos olhos do amante. A filosofia é amor em Platão. O papel do filósofo é revelar esse amor-filosofia para transformar o homem no melhor possível. Em suma, em todo o Banquete, como visto, há um autorretrato, há uma correspondência dramática entre Eros e Sócrates. Tanto um quanto o outro são devotos do belo, atraídos por jovens mancebos belos. Como Pênia, andam descalços, maltrapilhos, feios, têm em si, e reconhecem, a ignorância que lhes é latente; contudo, como Poros são bravos, corajosos e filósofos o tempo todo. E ainda mais, se se segue essa linha interpretativa em Platão, a própria sacerdotisa de Mantineia é prefiguração de Sócrates. Aquela que é agraciada pelos deuses (dio-tima) e que exerce um sacerdócio, através de um sacrifício filosófico (PINHEIRO, 2011, p. 64). Desse modo, diante de tudo visto até então, seja pela presença de Diotima, seja pelas características do amor elucidadas nesse diálogo, as quais se assemelham aos traços do mestre de Alcibíades, percebe-se a intenção do diálogo de apresentar Sócrates como a imagem mesma de Éros.

\section{CONCLUSÃO}

À guisa de uma conclusão é possível entender que, no Banquete de Platão, por meio do logos de Alcibíades, há uma apaixonada exaltação da figura de Sócrates como imagem mesma de Éros. Desde a entrada de Alcibíades no festim, passando pelos elementos postos por ele para elogiar Sócrates, até chegar ao quadro conclusivo de seu discurso; em tudo há uma busca de aproximar as características de Éros às características de Sócrates. Alcibíades, de modo claro, evidencia sua paixão que o parece consumir pelo seu mestre e, com isso, mostra que o amor socrático pode se concretizar na prática da vida pessoal. Fala através de imagens, formas dissimuladas de sua ironia. Os Silenos e sátiros Mársias são camuflagens, máscaras de Sócrates, que é uma contradição viva de feiura exterior e beleza interior; é encantador por excelência no ato de seduzir os que o cercam por meio de seu lógos. Em seu discurso, elogia as capacidades físicas, morais e intelectuais de Sócrates, dando a ele elementos atópicos. Com efeito, o Sócrates figurado pelo apaixonado Alcibíades é possuidor de uma personalidade fora de qualquer padrão, alguém, realmente, único. 
Artigo: A apaixonada exaltação da figura de Sócrates por meio do logos de Alcibíades no Banquete de Platão

\section{REFERÊNCIAS}

DORION, Louis-André. La figure paradoxale de Socrate dans les dialogues de Platon. In: BRISON, Luc; FRONTEROTTA, Francesco (eds.). Lire Platon. Paris: PUF, 2006.

FERRARI, Franco. Eros, paideia e filosofia: Sócrates entre Diotima e Alcibíades. Archai: Revista de Estudos sobre as Origens do Pensamento Ocidental, Coimbra, n. 9, p. 65-71, juldez. 2012.

FRANCO, I. Uma hipótese sobre o Banquete de Platão. Ethica, v. 15, p. 59-74, 2008.

HADOT, Pierre. Elogio de Sócrates. Tradução Flávio Loque e Loraine Oliveira. São Paulo: Edições Loyola, 2012.

HADOT, Pierre. Elogio da filosofia antiga. Tradução Flávio Loque e Loraine Oliveira. São Paulo: Edições Loyola, 2012.

HADOT, Pierre. Exercices spirituels et philosophie antique. Albin Michel, 2002.

HADOT, Pierre. Philosophy as a way of life. Oxford: Blackwell Publishers, 1999.

KENAAN, Vered. The Seduction of Hesiod: Pandora's Presence in Plato'sm Symposium. In: BOYS-STONES, George e HAUBOLD, Johannes (org.). Plato and Hesiod. Oxford: Oxford University Press, 2010.

LACAN, J. O Seminário. Livro 8. A Transferência 1960-1961. Tradução D. Estrada. Rio de Janeiro: Jorge Zahar, 1991.

MACEDO, D. O elogio do filósofo no Banquete de Platão. Síntese. v. 30, no. 98, p. 407 415, 2003.

NIETZSCHE, F. Crepúsculo dos ídolos. Tradução P. C. de Souza. São Paulo: Companhia das Letras, 2006.

NUSSBAUM, M. A fragilidade da bondade. Tradução Ana Aguiar Cotrim. São Paulo: Martins Fontes, 2009.

OLIVEIRA, L. A figura de Sócrates segundo Pierre Hadot. Archai, Brasília, no 18, p. $317-$ 346. Set.-dez. 2016.

OLIVEIRA, R. Eros, Natureza humana e filosofia no Banquete de Platão. Hypnos, São Paulo, v.36, p. 25-64, $1^{\circ}$ sem., 2016.

PINHEIRO, V. Introdução. In. PLATÃO. Banquete, Tradução Carlos Alberto Nunes. 3 ed. Belém: ed.UFPA, 2011.

PLATÃO. Banquete. Tradução Carlos Alberto Nunes. 3 ed. Belém: ed.UFPA, 2011. 
PLATÃO. Diálogos. Apologia de Sócrates, Critão, Menão, Hípias Maior e outros. Tradução Carlos Alberto Nunes. Belém: ed. UFPA, 1980.

REALE, G; ANTISERI, D. História da filosofia: Antiguidade e Idade Média. 8 ed. São Paulo: Paulus, 2003.

REALE, G. Eros, demonio mediadore. El juego de las mascaras en el Banquete de Platón. Traducción de Rosa Rius y Pere Salvat. Barcelona: Herder, 2004.

RIBEIRO, D. Conhecimento, amor, educação em Platão. 2005. Trabalho de conclusão do Programa de Pós-graduação em Educação (Dissertação). Universidade Católica de Goiás, Goiânia - GO, 2005. Acesso em:

http://tede.biblioteca.ucg.br/tde_busca/arquivo.php?codArquivo=412. 23 abr. 2014, 18:25:07.

SOUZA, J. Introdução. In. PLATÃO, O Banquete ou do amor. Tradução José Cavalcante de Souza. São Paulo: Difusão Europeia do Livro, 1966.

STRAUSS, L. On Plato's Symposium. Edited and whit a Foreword by Seth Bernadete. Chicago: The University of Chicago Press, 2001.

WOLFF, F. Sócrates. Tradução Franklin Leopoldo e Silva. São Paulo: Brasiliense, 1982.

ZANKER, P. The mask of Socrates: The Image of the Intellectual in Antiquity. Berkeley, Califórnia: University of California Press, 1995. 